Check for updates

Cite this: RSC Adv., 2017, 7, 24795

Received 22nd February 2017 Accepted 28th April 2017

DOI: $10.1039 / c 7 r a 02217 d$

rsc.li/rsc-advances

\title{
Structure and dynamics processes in free-base chlorins controlled by chemical modifications of macroring and aryl groups in meso-positions $\uparrow$
}

\begin{abstract}
J. Śniechowska, P. Paluch and M. J. Potrzebowski (D)*
In this work we present the synthesis, detailed structural characterization and analysis of molecular motion for unsymmetrical pyrrolidine-fused chlorins employing NMR, UV spectroscopy and DFT theoretical calculations. In samples, the meso-rings were modified by substitution of hydrogen by fluorine in ortho 1 and meta positions 2. The sample with perfluorinated ring 3 and phenyl derivative 4 were used as reference species. The assignment of signals was performed employing 2D NMR techniques. The rotational dynamics was examined by means of ${ }^{1} \mathrm{H}$ and ${ }^{19} \mathrm{~F}$ variable-temperature (VT) $1 D$ NMR spectroscopy and 2D EXSY experiments. The synergism of steric effect between pyrrolidine ring and meso-rings is unambiguously proved. Models 1 and 3 behave very similar, aromatic rings are rigid in temperature range 233-373 K. For sample 2 and 4 the distinct molecular dynamics was revealed. The barrier of rotation depends on localization of ring in the chlorin structure. Those which are bonded in the neighborhood of pyrrolidine ring are more rigid compared to those localized on the opposite site. The temperature is a trigger which sequentially releases the rotation of aromatic group in the desired localization. Introduction of fluorine in labeled position has influence on static geometry defined by saddling angles.
\end{abstract}

\section{Introduction}

Chlorins (hydroporphyrins) belong to the big family of porphyrinoids, an intriguing class of macrocyclic heteroorganic compounds widely distributed in the nature. Due to unique physical and chemical properties porphyrinoids play a key role in important biological processes including cell respiratory, light harvesting, and electron transfer. They are also a meaningful class of compounds from the practical point of view, intensively studied for application in catalysis, ${ }^{1}$ electronics, ${ }^{2}$ supramolecular chemistry ${ }^{3}$ and materials science. ${ }^{4}$ In addition, they are used as photosensitizers ${ }^{5}$ and anticancer or antibacterial drugs $^{6}$ in medicine. Excellent spectroscopic features of chlorins are reasons why these compounds found number of spectacular applications e.g. in photodynamic therapy, light-energy conversion systems or synthetic models of photosynthetic reaction centers.

Chlorins strongly absorb light in the near infrared part of electromagnetic spectrum and are relatively photostable. Introduction of halogen atoms (bromine, chlorine, or fluorine)

Centre of Molecular and Macromolecular Studies, Polish Academy of Sciences, Sienkiewicza 112, 90-363 Lodz, Poland.E-mail: marekpot@cbmm.lodz.pl

$\dagger$ Electronic supplementary information (ESI) available: NMR spectra, assignment of pyrrolidine-fused chlorine 2 and 3, absorption spectroscopy, HRMS analysis of compounds, Cartesian coordinates of computed structures of pyrrolidine-fused chlorines, NBO analysis. See DOI: 10.1039/c7ra02217d to the structure of tetrapyrrolic compounds enhances their photodynamic activity and controls chemical and spectroscopic properties. $^{6-9}$ The most important chemical modification is replacement of hydrogen by fluorine atoms or fluorinated moieties in the aromatic residues for meso-position. Skillful introductions of fluorine substituents into chlorins may increase photostability, lipophilicity and high level of singlet oxygen generation. ${ }^{10}$ It is well established that photonic properties of porphyrinoids are modulated by first-order molecular structure and conformation of meso-aryl groups with respect to the macroring plane. When the aromatic groups of tetra-mesoaryl-substituted porphyrin are coplanar with the macrocycle then aryl ring would be a part of porphyrin chromophore. Great efforts are being concentrated on the improvement of their properties and what follows on their possible applications.

The porphyrinoid derivatives have recently attracted much attention as components of nanomolecular machines; rotors, ${ }^{11,12}$ wheels, ${ }^{13}$ and gyroscopes. ${ }^{14}$ Application of the porphyrinoids in the construction of different types of functional molecular systems was reviewed by Michl and coworkers, ${ }^{15}$ Kay, Leigh, Zerbetto ${ }^{16}$ and others. ${ }^{17}$ Both metal free, as well as metal complexes of porphyrins, are used as building units of advanced machines. For instance, molecular oscillator based on supramolecular complexes of metalloporphyrin and fullerenes was described by Tashiro et al. ${ }^{18}$ Molecular gear assembling metalloporphyrins and cavitand were reported by Kobayashi and coworkers. ${ }^{19}$ Systems based on tin(rv) porphyrins as stator bearing at the meso-position, a monodentate 


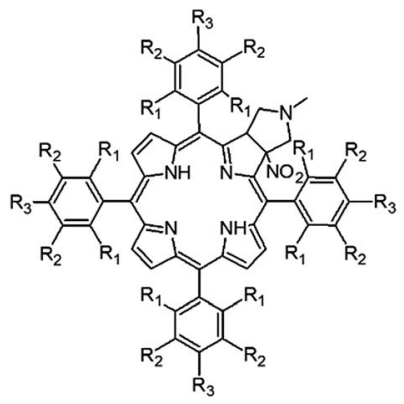

\begin{tabular}{|c|c|c|c|}
\hline Compound & $\mathbf{R}_{1}$ & $\mathbf{R}_{2}$ & $\mathbf{R}_{3}$ \\
\hline $\mathbf{1}$ & F & H & H \\
\hline $\mathbf{2}$ & H & F & H \\
\hline $\mathbf{3}$ & F & F & F \\
\hline $\mathbf{4}$ & H & H & H \\
\hline
\end{tabular}

Fig. 1 Structure of pyrrolidine-fused chlorins 1-4.

coordinating site and tridentate chelate on the different handles as rotors were shown. ${ }^{\mathbf{2 0 , 2 1}}$ Dynamics processes of porphyrinoids are also key element in construction of molecular switches and sensors. ${ }^{22}$ Ishihara et al. have reviewed number of derivatives which can be used for this purpose. ${ }^{23}$ Unique complexation properties of cyclic zinc(II) bisporphyrin with flexible linker were employed for synthesis of molecular switches with controllable photo and electro properties. ${ }^{24}$ The photomolecular switches with strong absorption properties of porphyrinoids were also reported. $^{25}$

The porphyrinoid derivatives can undergo complex motions including positional displacements of submolecular components and/or local molecular dynamics both in the liquid and solid states. Knowledge about the nature of these processes and tools for controlling the motion in molecular machines is a key information determining the synthetic strategy. The best recognized dynamics process in porphyrinoids is rotation of aromatic rings in meso-position. Gottwald and Ullman ${ }^{26}$ were the first to observe rotation of the phenyl rings in meso-tetraphenylporphyrin. This problem was discussed in detail for different porphyrin derivatives in review articles and textbooks. $^{27-29}$

The local molecular motion of meso-aryl rings can be restricted or eliminated by hindrance effect. In the most common approach introducing the bulky group at $\beta$-position of pyrrolic ring and steric interactions with adjacent residue has influence on the rotation barrier. Such phenomenon was reported in detail by Noss et al. ${ }^{\mathbf{3 0}}$ and by other authors for number of chemically modified porphyrins. To the best of our knowledge the literature about dynamics process in chlorins is rather limited. Stolzenberg et $a{ }^{31}$ reported activation barriers for meso-aryl group rotation in metal-free and titanyl hydroporphyrins. It was found that activation barriers in these compounds ranged from 15.6 to $18.6 \mathrm{kcal} \mathrm{mol}^{-1}$.

In this paper we show how dynamic processes in the chlorins can be controlled and sequentially modulated by combination of steric effects in macrocyclic framework and aryl residues in mesoposition. For this purpose we employ derivatives as shown in Fig. 1.

\section{Results and discussion}

\section{Synthesis of unsymmetrical chlorins}

It is well-known that 1,3-dipolar cycloaddition ${ }^{32-36}$ is an useful method of transformation of porphyrins into chlorins. Based on
Cavaleiro' $\mathrm{s}^{37}$ discovery that porphyrins could act as dipolarophiles, we synthesized target compounds. The synthesis of compounds is a multi-step sequence and synthetic route is presented in Scheme 1. The starting porphyrins 5 and $\mathbf{6}$ were synthesized according to procedures described in the literature. Porphyrin $\mathbf{5}$ was prepared from aldehyde and pyrrole with a mixture of nitrobenzene and acetic $\operatorname{acid}^{38}$ as a solvent. For porphyrin 6 we adopted Adler and Longo procedure ${ }^{39}$ involving the heating of equimolar amounts of the fluorinated aldehyde and pyrrole in refluxing propionic acid. In both methods crude products were crystallized. Compounds 7 and $\mathbf{8}$ were purchased from PorphyChem. Treatment of free-base porphyrins 5-8 with cooper acetate in chloroform afforded the corresponding copper complex of porphyrins. Nitration at $\beta$-position was achieved by the reaction of copper(II) nitrate with complex 9-12 in mixture acetic acid/acetic anhydride in chloroform in reflux temperature. Subsequent demetallation under strong acid conditions afforded the expected $\beta$-nitro-tetra-aryloporphyrins 17-20. After that, the porphyrins were converted to pyrrolidine-fused chlorins by the reaction with azomethine ylide generated in situ from sarcosine and paraformaldehyde.

\section{Geometry of unsymmetrical chlorins - theoretical models}

The starting point for discussion of structure and dynamic processes for derivatives under investigation is knowledge about preferable conformation. The static and dynamic aspects of the conformation of meso-tetra-arylporphyrinoids were discussed in number of papers where different methodologies were employed. In the case when the sample forms crystals with quality suitable for monocrystal studies the X-ray crystallography is mainly used for search of conformation. When the crystallization process fails, the alternative approaches are theoretical calculations. It is a case of samples researched in our project as we were not able to grow good quality crystals.

Computer methods allow analyzing both the conformation of the meso-phenyl rings and the deformation of the porphyrinoid macrocycle, as well as the barriers of rotation of the meso-phenyl rings (atropisomerism). The measure of nonplanar distortions is shown by the saddling dihedral angles labelled as $\chi_{1}, \chi_{2}, \chi_{3}$, $\chi_{4}$ (for notation used see Table 1 ). It is interesting to note that values of these angles differ between derivatives. The largest values suggesting the macrocycle deformation are found for sample $\mathbf{2}$ and $\mathbf{4}$ while in contrast samples $\mathbf{1}$ and $\mathbf{3}$ are almost planar. Moreover, comparison of sample 1 and 2 reveals that the position of fluorine atoms in the aryl ring is a crucial factor influencing the nonplanarity/planarity of macroring. Orthofluorines strongly interact with macrocycle leading to the flattening of structure. This effect in pictorial form is shown in Fig. 2.

Another interesting structural feature is conformation of aryl rings with respect to the macroring plane. In each case aryl groups are in gauche conformation. However, more detailed analysis and measurement of the torsional angles between the planes of aryl groups shows intriguing features related to the position of fluorine in rings. The $\chi_{5}, \chi_{6}$ torsional angles are defined as shown in Table 1. As one can see the values for 

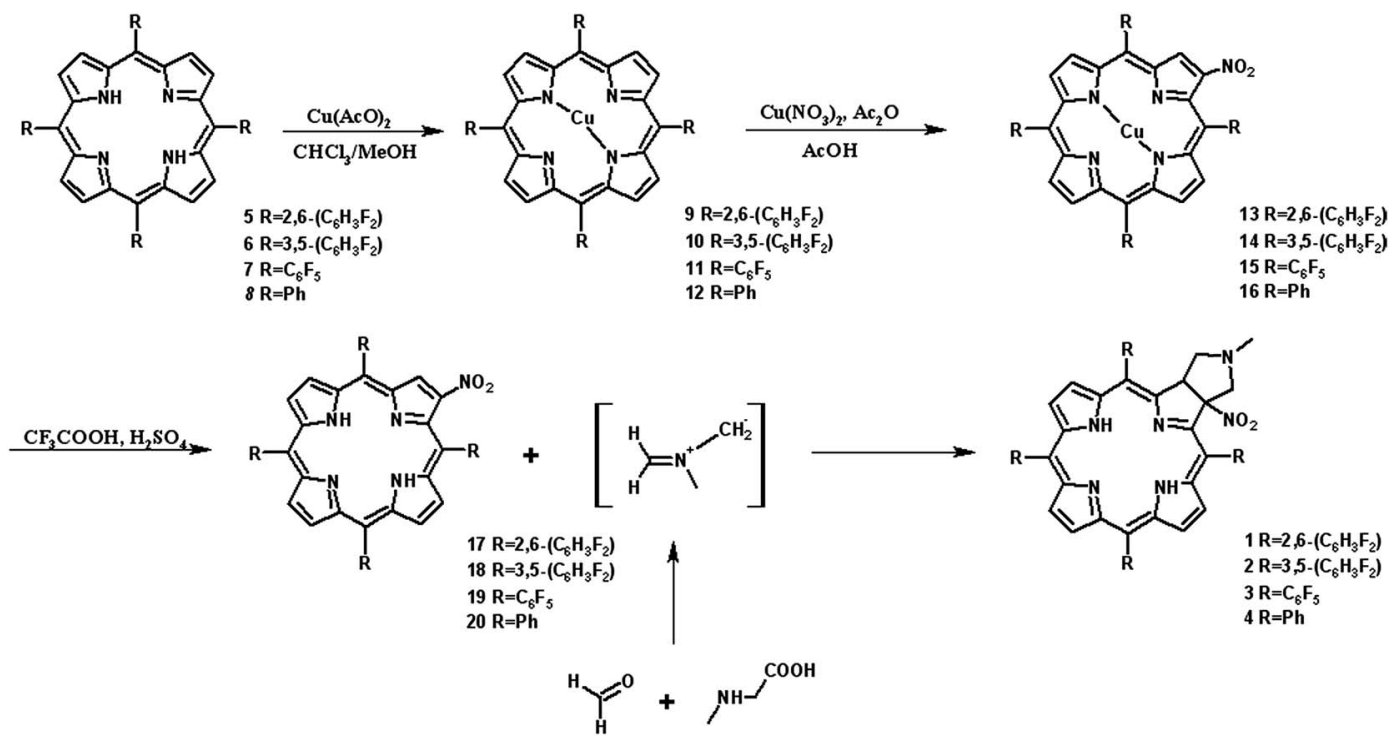

Scheme 1 Synthetic route.

Table 1 Saddling dihedral angles of pyrrolidine-fused chlorins 1-4
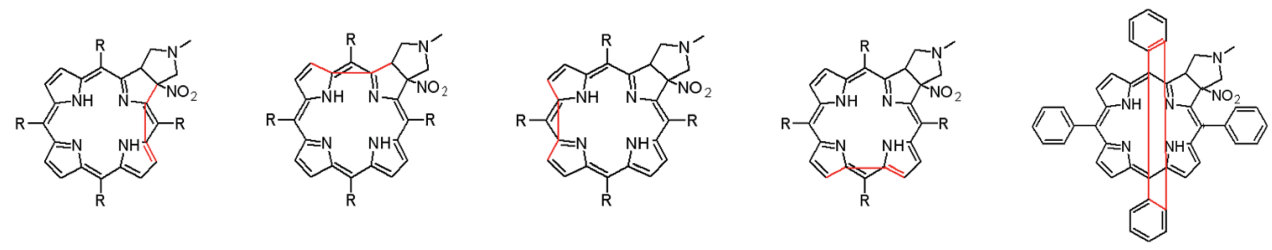

\begin{tabular}{rr}
$\chi_{2}$ & \multicolumn{1}{c}{$\chi_{3}$} \\
4.65 & 3.09 \\
9.65 & 11.57 \\
4.98 & 3.76 \\
10.12 & 12.04
\end{tabular}

$\chi_{4}$

1.07

9.25

1.68

10.05

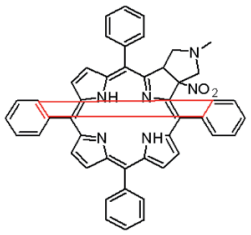

$\chi_{6}$

11.14

29.25

10.95

32.83 samples $\mathbf{2}$ and $\mathbf{4}$ again are very similar. It clearly proves that fluorine atoms which are not in direct contact with macroring weakly interact with it. During further comparison of the values of $\chi_{5}$ and $\chi_{6}$ we noted that the largest distinction is seen for compound 3. It suggest that bulky fluorine groups located in the neighbourhood of nitro residue "feel" the steric effect. Concluding, the theoretical calculations and computed models clearly show that position of substitution of fluorine in the meso-aromatic ring has strong influence on the preferable conformation. Thus we can anticipate that molecular dynamics of these groups will also be distinctive.

\section{Correlation between molecular structure and optical properties}

The absorption spectra of synthesized pyrrolidine-fused chlorins 1-4 were measured in dichloromethane and toluene. Fig. 3 shows the absorption spectra in toluene at room temperature and the band maxima of absorption and molar absorbance coefficients were summarized in Table 2.

The absorption spectra of 1-4 differ in respect of the positions and the intensity ratios of the bands as well as a molar absorbance coefficient. The positions of the Soret band are

a)

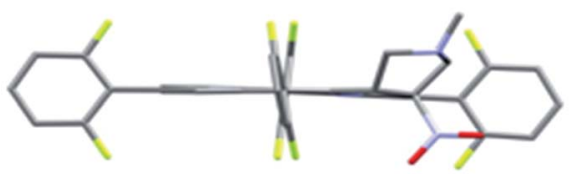

b)

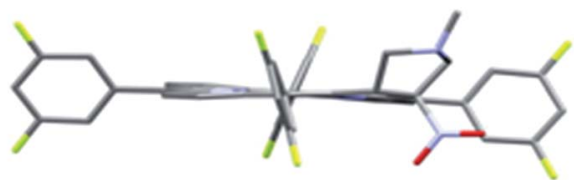

Fig. 2 DFT $(B 3 L Y P / 6-311++g(d, p))$ optimized structures of chlorins 1 and 2 . 

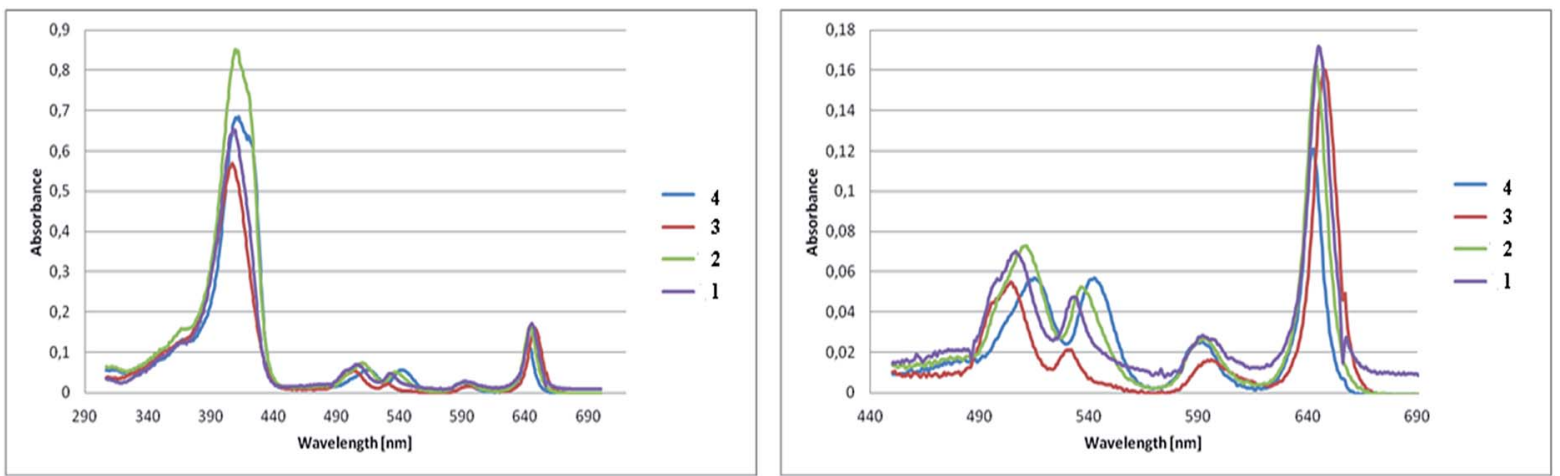

Fig. 3 (Left) Absorption spectra at room temperature of pyrrolidine-fused chlorins 1-4 in toluene solution. (Right) Expansion of 440-690 nm region of spectra. Molar concentrations of the chlorins 1-4 were roughly the same.

nearly identical with each other. Compared to the chlorin 4 , the Soret bands for fluorinated analogues were moved, but the shifts are not significant. Major changes are noticeable for Q band. It is apparent from the absorption bands that small shifts in the absorption maxima occur as the results of substitution and amount of fluorine atoms in the chlorins. With the increase in the number of fluorine atoms in the molecule, the strongest absorption bands are shifted bathochromically compared to the non-fluorinated chlorin $\mathbf{4}$. The number and location of fluorine atoms affects also the intensity of the absorption. The highest value of molar absorbance coefficient at room temperature in toluene is related to chlorin $\mathbf{2}$, the next very close is for sample $\mathbf{4}$.

Table 2 Molar absorbance coefficient of the chlorins 1-4

\begin{tabular}{lll}
\hline Compound & $\begin{array}{l}\text { Soret band } \\
{[\mathrm{nm}]}\end{array}$ & $\begin{array}{l}\text { Molar absorbance } \\
\text { coefficient }\left[\mathrm{dm}^{3} \mathrm{~mol}^{-1} \mathrm{~cm}^{-1}\right] \\
\text { in toluene }\end{array}$ \\
\hline $\mathbf{1}$ & 408 & 141040 \\
$\mathbf{3}$ & 409 & 180726 \\
$\mathbf{4}$ & 408 & 120968 \\
& 411 & 163822
\end{tabular}

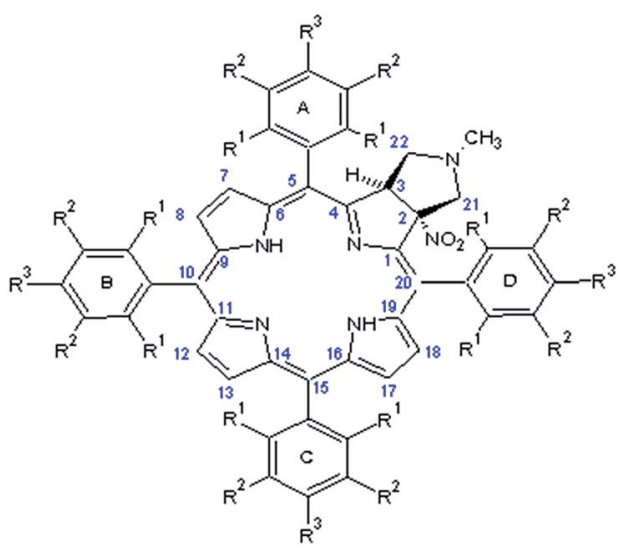

Scheme 2 General labeling and numeration in chlorins.

\section{NMR studies of chlorins 1-4}

The crucial information which is prerequisite for discussion of local molecular motion is the precise assignment of meso-aryl groups and their localization in the structure of chlorins. The notation which we used in this project for labeling of A, B, C, D aryls in meso-positions is shown in Scheme 2.

NMR spectroscopy is a technique which provides straightforward structural information about geometry of compounds. For chlorins 1-4 we have carried out NMR measurements at ambient temperature employing $1 \mathrm{D}$ and $2 \mathrm{D}$ homo- and heteronuclear correlations. In the case of samples 1-3 which are fluorine derivatives, ${ }^{19} \mathrm{~F}$ nucleus is an additional structural probe invaluable in further studies. Fig. 4 shows standard ${ }^{1} \mathrm{H}$ and ${ }^{19} \mathrm{~F}$ NMR spectra for sample 1.

For each sample a broad singlet at -1.5 to $-3.5 \mathrm{ppm}$ representing inner pyrrolic $\mathrm{NH}$ groups was observed. In all compounds signals for $\mathrm{H}_{3}, \mathrm{H}_{21}, \mathrm{H}_{21^{\prime}}$ and $\mathrm{H}_{22}, \mathrm{H}_{22^{\prime}}$ found in the range 2-6 ppm are well resolved and can be unambiguously assigned (Fig. 4a). The spin system pattern clearly confirms that $\mathrm{N}$-methylpyrrolidine ring is connected to $\mathrm{C}_{2}$ and $\mathrm{C}_{3}$ carbons. In other case, for substitution at $\mathrm{C}_{7} / \mathrm{C}_{8}$ or $\mathrm{C}_{12} / \mathrm{C}_{13}$ as well $\mathrm{C}_{17} / \mathrm{C}_{18}$ the six spin system should be observed.

The detailed description of strategy used for assignment of A, B, C, D aryl residues we show employing sample $\mathbf{1}$ and sample 4. In other cases the employed methodology is similar. To specify the describing of the spatial alignment for moieties under investigation we adopted the convention assuming that the pyrrolidine ring is above macroring plane while nitro group is below. Consequently, fluorine or hydrogen atoms in meso-aryl rings which are at the same side as the nitro substituent were denoted as down, and up when they are on the opposite side.

In analysis of fluorinated samples, homonuclear ${ }^{1} \mathrm{H}-{ }^{1} \mathrm{H}$, ${ }^{19} \mathrm{~F}^{19} \mathrm{~F}$ 2D NMR correlations and experiments based on ${ }^{1} \mathrm{H}^{-19} \mathrm{~F}$ Heteronuclear Overhauser Effect (HOESY) were found to be the most informative. The ${ }^{19} \mathrm{~F}-{ }^{19} \mathrm{~F}$ COSY spectrum carried out with proton decoupling (Fig. 5) allowed us to assign pairs of fluorine atoms belonging to individual meso-aryl rings. As can be seen, the influence of pyrrolidine ring and nitro group on ${ }^{19} \mathrm{~F}$ chemical shifts of neighbouring aryls in meso-position is significant. The distinction of $\delta_{19 \mathrm{~F}}$ for $u p$ and down fluorine atoms is $c a .1 \mathrm{ppm}$. 


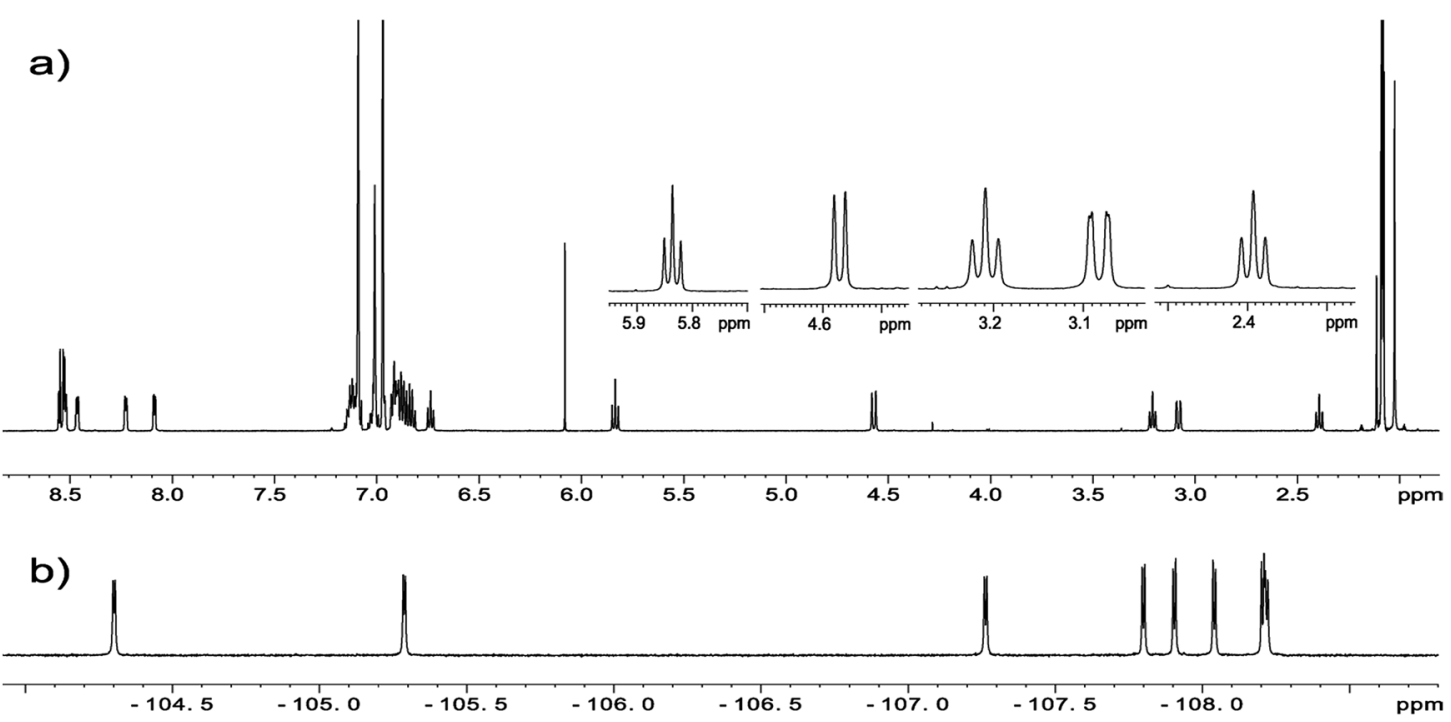

Fig. 4 (a) ${ }^{1} \mathrm{H}$ NMR spectrum of chlorin 1 and expansion of $2-6$ ppm region showing $\mathrm{H}_{21} / \mathrm{H}_{21^{\prime}}, \mathrm{H}_{22} / \mathrm{H}_{22^{\prime}}$ and $\mathrm{H}_{23}$ protons. (b) ${ }^{19} \mathrm{~F} N M R$ spectrum of chlorin 1 recorded in toluene- $\mathrm{d}_{8}$ at $600 \mathrm{MHz}$.

Next, we carried out ${ }^{1} \mathrm{H}^{19} \mathrm{~F}$ HOESY experiment (Fig. 6) assuming that this correlation, showing dipolar interactions by space will enable us to distinguish spatial localization of fluorine atoms. The analysis began with $\mathrm{H}_{3}, \mathrm{H}_{21}, \mathrm{H}_{21^{\prime}}$ and $\mathrm{H}_{22}, \mathrm{H}_{22^{\prime}}$ signals for which the assignment is unquestionable. The position of $\mathrm{F}_{\mathrm{D} \text {-up }}$ is concluded on the base of correlation between $\mathrm{H}_{21}$ and $\mathrm{H}_{21^{\prime}}$ (Fig. 6), while $\mathrm{F}_{\mathrm{A} \text {-up }}$ on correlation between $\mathrm{H}_{22}$ and $\mathrm{H}_{22^{\prime}} \cdot \mathrm{F}_{\mathrm{A} \text {-down }}$ shows the correlation peak with $\mathrm{H}_{3} . \mathrm{F}_{\mathrm{D} \text {-up }}$ and $\mathrm{F}_{\mathrm{D} \text {-down }}$ correlate with $\mathrm{H}_{18}$. In the same way $\mathrm{H}_{7}$ correlates with $\mathrm{F}_{\mathrm{A} \text {-up }}$ and $\mathrm{F}_{\mathrm{A} \text {-down }}$. Correlation between $\mathrm{H}_{17}$ and two fluorine signals provides information about assignment of $\mathrm{F}_{\mathrm{C} \text {-up }}$ and $\mathrm{F}_{\mathrm{C} \text {-down }}$. Position of $\mathrm{F}_{\mathrm{C} \text {-up }}$ and $\mathrm{F}_{\mathrm{C} \text {-down }}$ is assigned by correlation with $\mathrm{H}_{13}$. Assignment of $\mathrm{F}_{\mathrm{B} \text {-up }}$ and $\mathrm{F}_{\mathrm{B} \text {-down }}$ was not possible, but these two signals were assigned via correlation between $\mathrm{H}_{8}$ and $\mathrm{H}_{12}$.

Interesting effects were observed in ${ }^{1} \mathrm{H}^{-19}{ }^{19}$ HETCOR (Fig. 7) spectrum which shows a strong correlation between $\mathrm{H}_{21^{\prime}}-\mathrm{F}_{\mathrm{D} \text {-up }}$

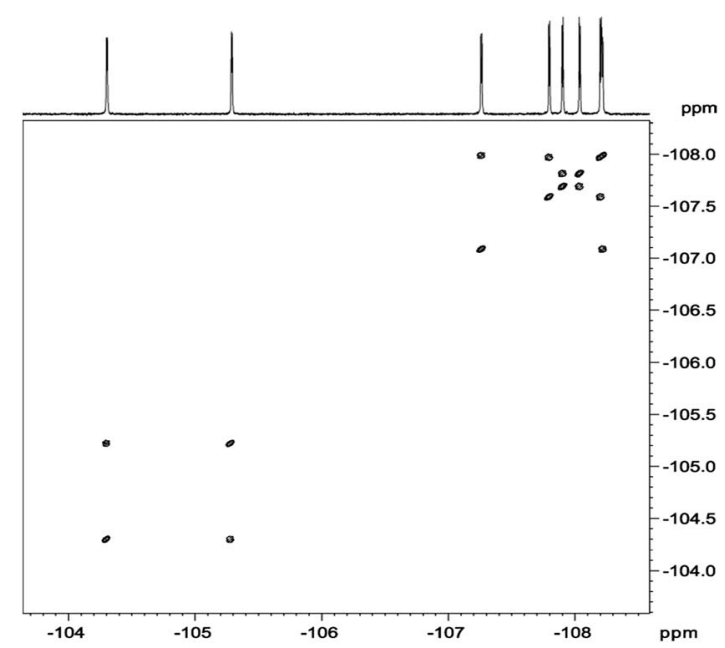

Fig. $5{ }^{19} \mathrm{~F}\left\{{ }^{1} \mathrm{H}\right\}-{ }^{19} \mathrm{~F}\left\{{ }^{1} \mathrm{H}\right\}$ DQF-COSY spectrum of chlorin 1 recorded in toluene- $d_{8}$. The spectrum obtained at $600 \mathrm{MHz}$ spectrometer. and weaker correlation between $\mathrm{H}_{22^{\prime}}-\mathrm{F}_{\mathrm{A} \text {-up }}$. At the first glance this correlation via 7 bonds is very surprising. However inspection of DFT optimized (at B3LYP/6-311++g(d,p) level) structure gives reasonable explanation of this effect. Distance between $\mathrm{H}_{21^{\prime}}-\mathrm{F}_{\mathrm{D} \text {-up }}$ is $2.50 \AA$ and $\mathrm{H}_{22^{\prime}}-\mathrm{F}_{\mathrm{A} \text {-up }}$ is $3.22 \AA$. In this case the so called " $J$ coupling through space" operates due to existence of an interaction between antibonding orbitals. Such coupling is well described in literature mostly in case of ${ }^{19} \mathrm{~F}-{ }^{19} \mathrm{~F}$ and

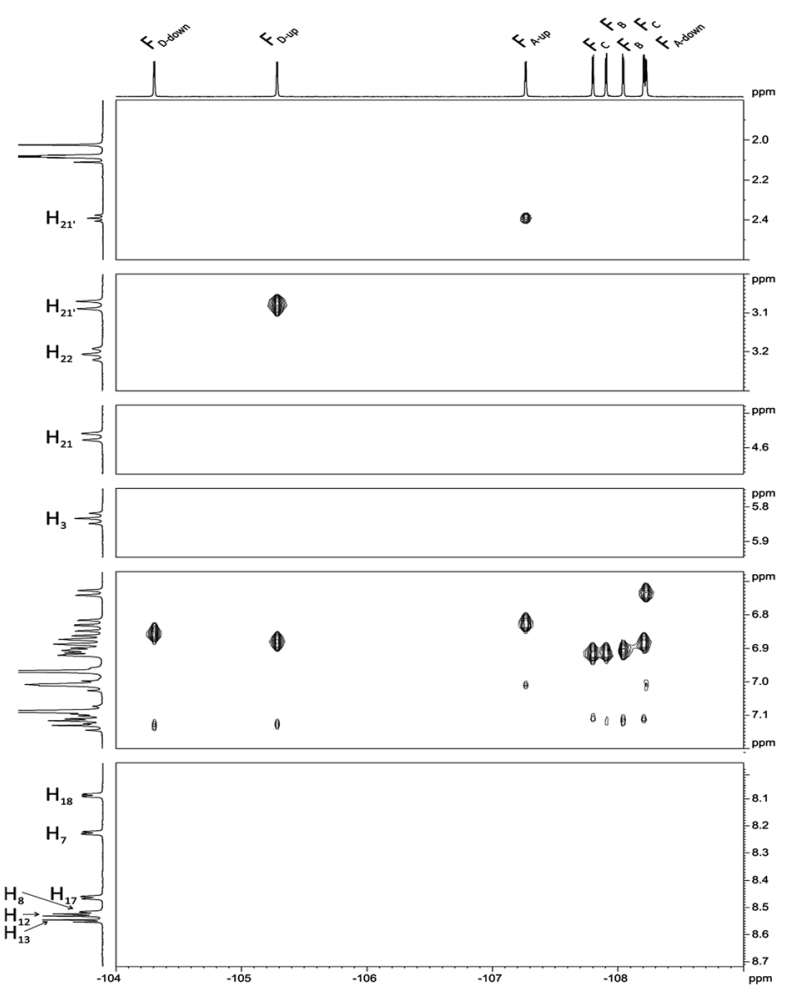

Fig. $6{ }^{1} \mathrm{H}-{ }^{19} \mathrm{~F}$ HOESY spectrum of chlorin 1 recorded in toluene- $\mathrm{d}_{8}$. The spectrum obtained at $600 \mathrm{MHz}$ spectrometer. 


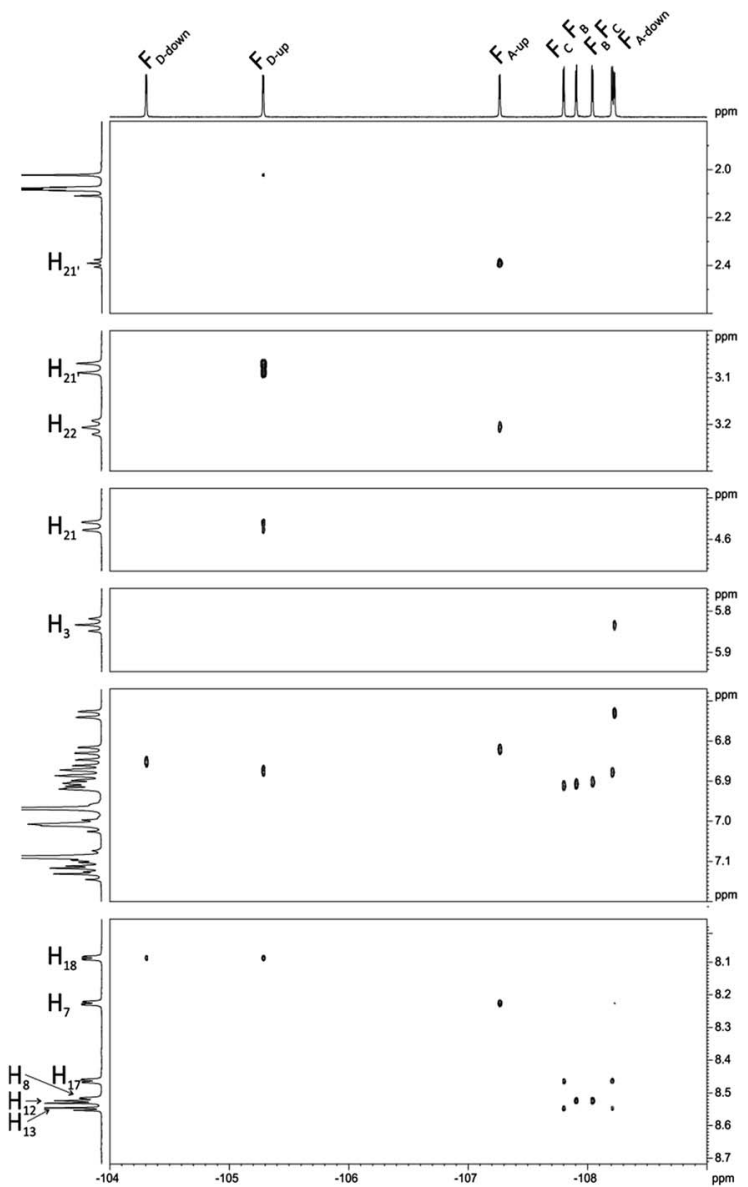

Fig. $7{ }^{1} \mathrm{H}-{ }^{19} \mathrm{~F}$ HETCOR spectrum of chlorin 1 recorded in toluene- $\mathrm{d}_{8}$. The spectrum obtained at $600 \mathrm{MHz}$ spectrometer.

${ }^{1} \mathrm{H}^{-19} \mathrm{~F}$ coupling but also for ${ }^{19} \mathrm{~F}-{ }^{15} \mathrm{~N},{ }^{19} \mathrm{~F}^{31} \mathrm{P}^{31}{ }^{19} \mathrm{~F}^{77} \mathrm{Se}^{40} \mathrm{H}_{21^{\prime}}$ $\mathrm{F}_{\mathrm{D} \text {-up }}$ interaction also causes additional $(1.8 \mathrm{~Hz})$ splitting of $\mathrm{H}_{21}$ signal in ${ }^{19} \mathrm{~F}$ non decoupled ${ }^{1} \mathrm{H}$ spectrum. $\mathrm{H}_{22^{\prime}}-\mathrm{F}_{\mathrm{A} \text {-up }}$ interaction is much weaker and causes only little line broadening in ${ }^{19} \mathrm{~F}$ non decoupled ${ }^{1} \mathrm{H}$ spectrum (this coupling cannot be easily directly measured and we estimated it to be $0.5 \mathrm{~Hz}$ ).

For structural assignment of sample $\mathbf{4}$ we employed classical NMR strategy based on the analysis of homonuclear $2 \mathrm{D}^{1} \mathrm{H}^{-1} \mathrm{H}$ COSY (Fig. 8) and ${ }^{1} \mathrm{H}^{1}{ }^{1} \mathrm{H}$ ROESY spectra (Fig. 9). As in the previous case we begun the structural study with diagnostic signals $\mathrm{H}_{3}, \mathrm{H}_{21}, \mathrm{H}_{21^{\prime}}$ and $\mathrm{H}_{22}, \mathrm{H}_{22^{\prime}}$. Knowing the chemical shifts of these signals it was possible to assign protons in $\beta$-pyrrolic position. Proton in $o-\mathrm{H}_{\mathrm{A} \text {-up }}$ position was assigned by correlation with $\mathrm{H}_{22}$ and $\mathrm{H}_{22^{\prime}}$ protons in ${ }^{1} \mathrm{H}^{-1} \mathrm{H}$ ROESY spectrum. Having in mind $o-\mathrm{H}_{\mathrm{A} \text {-up }}$ correlation it was further possible to assign $\mathrm{H}_{7}$ proton in $\beta$-pyrrolic positions. In the similar way we assigned $\mathrm{H}_{18}$ using correlation with $o-\mathrm{H}_{\text {D-up }}$. Correlation between $\mathrm{H}_{18}$ and $o$ - $\mathrm{H}_{\text {D-up }}$ as well $\mathrm{H}_{8}$ and $\mathrm{H}_{17}$ was done using ${ }^{1} \mathrm{H}^{-1}{ }^{1} \mathrm{H}$ COSY experiment and their correlation with previously assigned $\mathrm{H}_{7}$ and $\mathrm{H}_{18}$. It was impossible to assign positions of up and down oprotons in B and $\mathrm{C}$ rings. Both up/down protons were assigned by correlation with $\mathrm{H}_{8}$ or $\mathrm{H}_{17}$ for $\mathrm{C}$ and $\mathrm{B}$ rings respectively in ${ }^{1} \mathrm{H}_{-}{ }^{1} \mathrm{H}$ ROESY spectrum. $\mathrm{H}_{12}$ and $\mathrm{H}_{13}$ signals were assigned by correlation with $o$-protons of $\mathrm{C}$ or $\mathrm{B}$ ring. Due to high

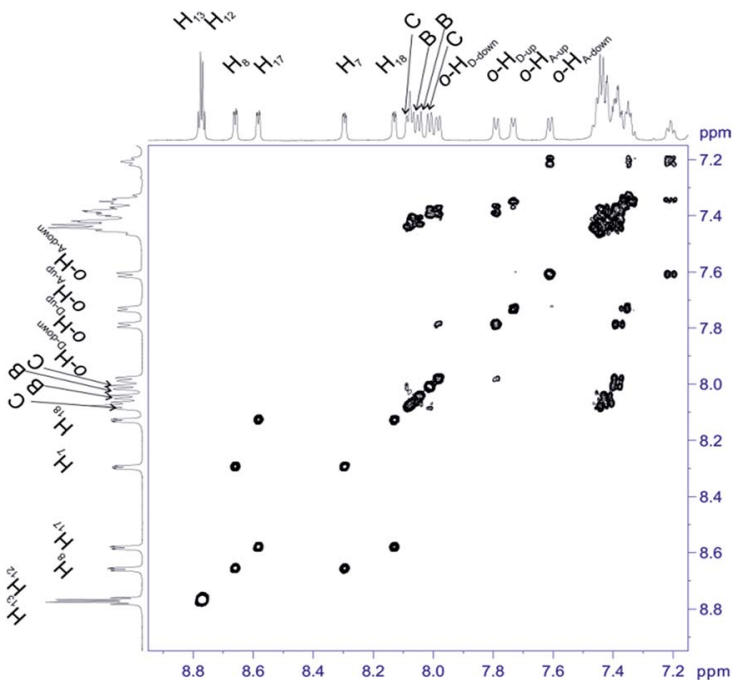

Fig. 8 Most diagnostic part of ${ }^{1} \mathrm{H}-{ }^{1} \mathrm{H}$ COSY spectrum of compound 4 recorded at $243 \mathrm{~K}$ in toluene- $\mathrm{d}_{8}$. The spectrum obtained at $600 \mathrm{MHz}$ spectrometer.

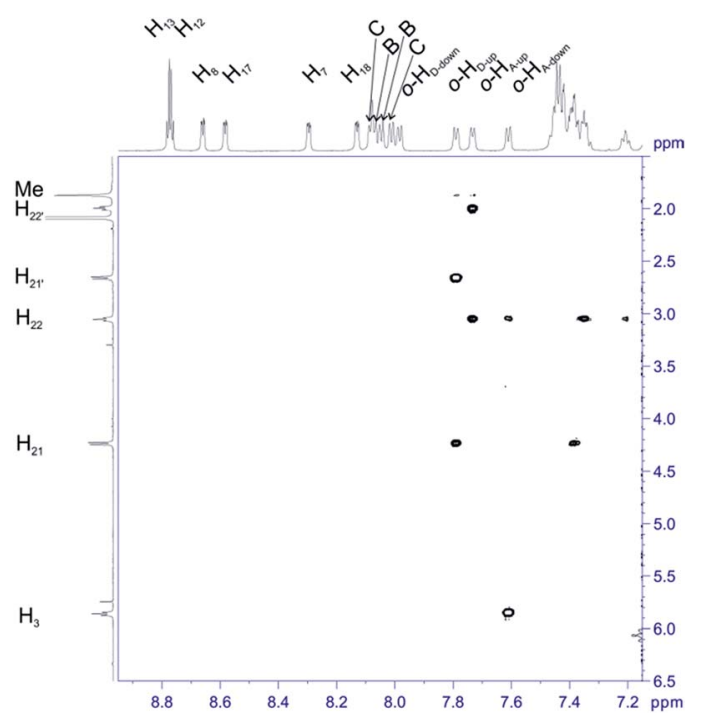

Fig. 9 The most diagnostic part of ${ }^{1} \mathrm{H}-{ }^{1} \mathrm{H}$ ROESY spectrum of compound 4 recorded at $243 \mathrm{~K}$ in toluene- $d_{8}$. The spectrum obtained at $600 \mathrm{MHz}$ spectrometer.

overlapping even in 2D experiment, and additional complication caused by chemical exchange, it was impossible to assign meta and para protons of phenyl rings.

\section{Dynamics of meso rings}

Having the set of assigned ${ }^{1} \mathrm{H}$ and ${ }^{19} \mathrm{~F}$ signals, we were able to investigate the molecular dynamics of meso-aryl rings in relation to their position in the structure and in function of temperature. In all cases we have carried out variabletemperature (VT) NMR measurements in the range of 233 to $353 \mathrm{~K}$ (sample 1 and 2) and in the range of 283-353 K (sample 3) employing toluene- $\mathrm{d}_{8}$ as solvent. Fig. 10 shows the $1 \mathrm{D}{ }^{19} \mathrm{~F}$ VT NMR spectra for samples 1-3. 


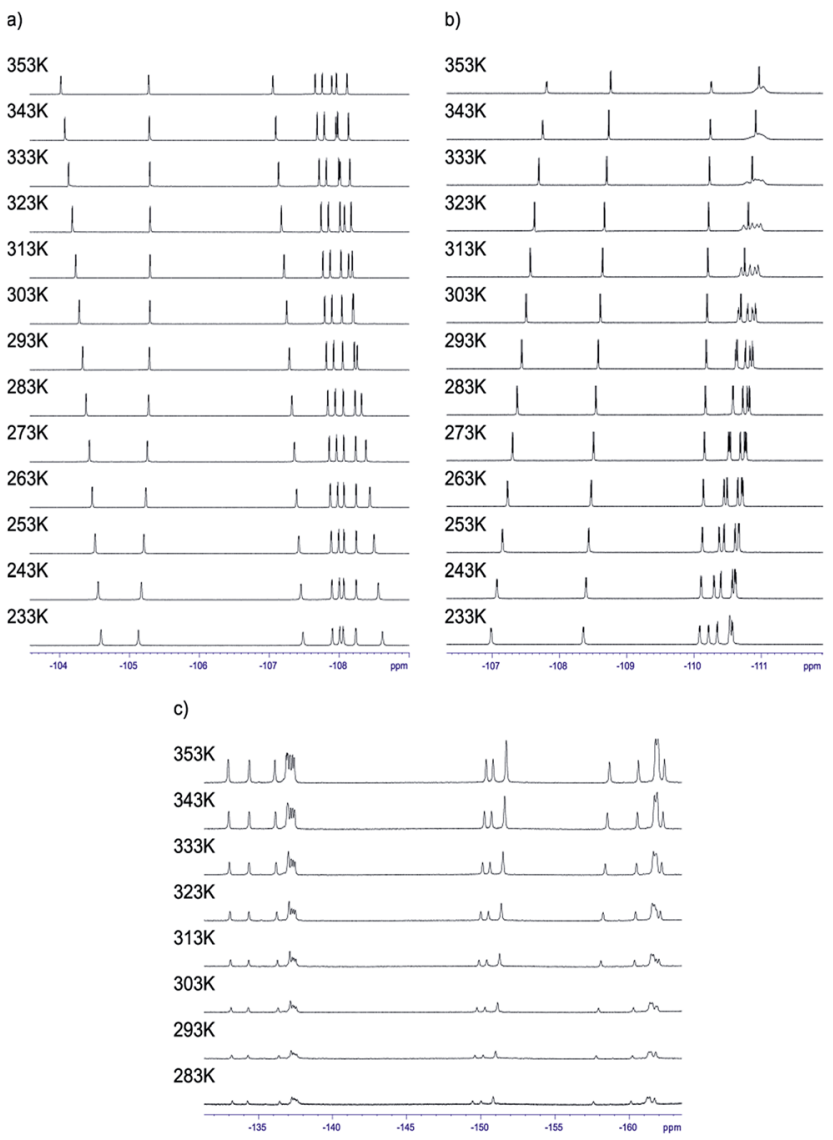

Fig. $101 \mathrm{D}{ }^{19} \mathrm{~F}$ VT NMR spectra in the range of $233-353 \mathrm{~K}$ of compound (a) 1 and (b) 2 . In case compound 3 (c) due to low solubility of this compound spectra were measured starting from $283 \mathrm{~K}$. The spectra were recorded in toluene- $d_{8}$ at $600 \mathrm{MHz}$.

In the case of sample 1 and sample 3 the line broadening of ${ }^{19} \mathrm{~F}$ signals caused by rotation of fluorophenyl rings in mesopositions is not observed. The only visible thermal effect is a small change of chemical shifts (temperature drift). This temperature shift effect may be caused by changing the solvation sphere and change of interactions between chlorin and toluene molecules. Sample 2 behaves differently when compared to $\mathbf{1}$ and $\mathbf{3}$. In this case we observed line shape effect for fluorine atoms representing $\mathrm{B}$ and $\mathrm{C}$ rings. This process begun at $303 \mathrm{~K}$. Starting from $318 \mathrm{~K}$ it was not possible to observe multiplicity (doublet) of signals for B and C rings. Near temperature $338 \mathrm{~K}$ signals representing $\mathrm{B}$ and $\mathrm{C}$ rings are very broad. At $353 \mathrm{~K}$ we monitored two separated, quite broad signals for averaged B and C fluorine atoms. These signals sharpened when temperature was further increased. It is worth to express that line broadening was not observed for fluorine atoms representing $\mathrm{A}$ and $\mathrm{D}$ rings. It suggests that these residues are rigid in the broad range of temperature. Going further with analysis of molecular motion for B and C rings we calculated (from line shape fitting) exchange barriers in temperature range 308-373 K. Having these values it was possible to calculate the activation energy $\left(E_{\mathrm{a}}\right)$ of rotation from Arrhenius plot (Fig. 11). The $E_{\mathrm{a}}$ values were found to be $18.5 \pm 0.5$ and $17.7 \pm$

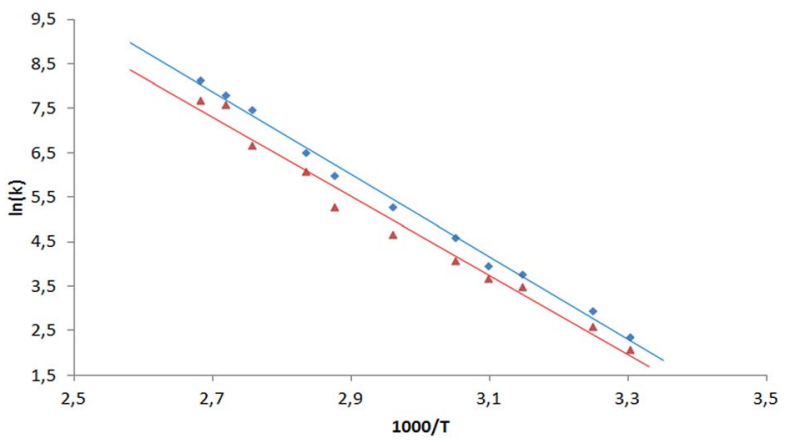

Fig. 11 Arrhenius plot for exchange rate of ${ }^{19} \mathrm{~F}$ signals of $\mathrm{B}$ (blue square) and C (red triangle) rings for sample 2.

$0.8 \mathrm{kcal} \mathrm{mol}^{-1}$ for B and C rings, respectively. These energies are very close to each other and similar to data available in literature for another porphyrinoids (subporphyrins, ${ }^{41}$ porphyrins, metalloporphyrins and metallo-chlorins ${ }^{15}$ ). Our studies unambiguously proved that the substitution in $\beta$-position have significant influence on molecular dynamics of meso-rings. This dynamic process can be controlled by synthesis of derivatives substituted by fluorine atom in assumed position of aromatic group.

Further evidence confirming the distinct molecular motion of meso aromatic groups for fluorine derivatives 1-3 was obtained by employing ${ }^{19} \mathrm{~F}\left\{{ }^{1} \mathrm{H}\right\}-{ }^{19} \mathrm{~F}\left\{{ }^{1} \mathrm{H}\right\}$ 2D EXSY experiment (Fig. 12). Using this technique it is possible to observe correlation between the exchanged signals even in slow chemical exchange regime.

For sample 1 and 3 even at $353 \mathrm{~K}$ it was not possible to observe correlation signals. It means that all rings are static in the $233-353 \mathrm{~K}$ temperature range. It is worth to express that in the case of 2,6-disubstituted phenyl rings, 1 steric hindrance caused by substitution of aromatic groups has great influence on the rotation barrier and excludes dynamic processes in each pyrrolidine-fused chlorin in meso-position.

The case of sample 2 is different. As we mentioned above, 1D NMR analysis proved the molecular motion of B and $\mathrm{C}$ mesorings. To answer whether $\mathrm{A}$ and $\mathrm{D}$ rings are completely static in NMR time scale, or if they exhibited small mobility, we performed ${ }^{19} \mathrm{~F}\left\{{ }^{1} \mathrm{H}\right\}-{ }^{19} \mathrm{~F}\left\{{ }^{1} \mathrm{H}\right\}$ EXSY experiment at temperature $353 \mathrm{~K}$. In this case it was easy to observe the exchange signals between $\mathrm{F}_{\mathrm{A} \text {-up }}-\mathrm{F}_{\mathrm{A} \text {-down }}$ and $\mathrm{F}_{\mathrm{D} \text {-up }}-\mathrm{F}_{\mathrm{D} \text {-down }}$, so these signals were in slow exchange limit. It means that $\mathrm{B}$ and $\mathrm{C}$ rings are much more mobile than A and D rings, but all of the rings exhibit mobility at $353 \mathrm{~K}$ in NMR time scale.

In the case of sample 4 we do not have such an excellent NMR probe for analysis of molecular motion as fluorine nucleus. Thus the basic source of information is ${ }^{1} \mathrm{H}$ NMR spectroscopy. Fig. 13 shows the aromatic region of meso-residues in the 233-353 $\mathrm{K}$ temperature range.

In this case it was possible to observe lineshape effect for ortho signals of $\mathrm{B}$ and $\mathrm{C}$ ring starting from temperature $293 \mathrm{~K}$. Coalescence of $\mathrm{H}_{\mathrm{B} \text {-up }}-\mathrm{H}_{\mathrm{B} \text {-down }}$ and $\mathrm{H}_{\mathrm{C} \text {-up }}-\mathrm{H}_{\mathrm{C} \text {-down }}$ pairs of signals were observed at temperature $333 \mathrm{~K}$. Further increasing of temperature caused reducing of line widths. For A ring it was 


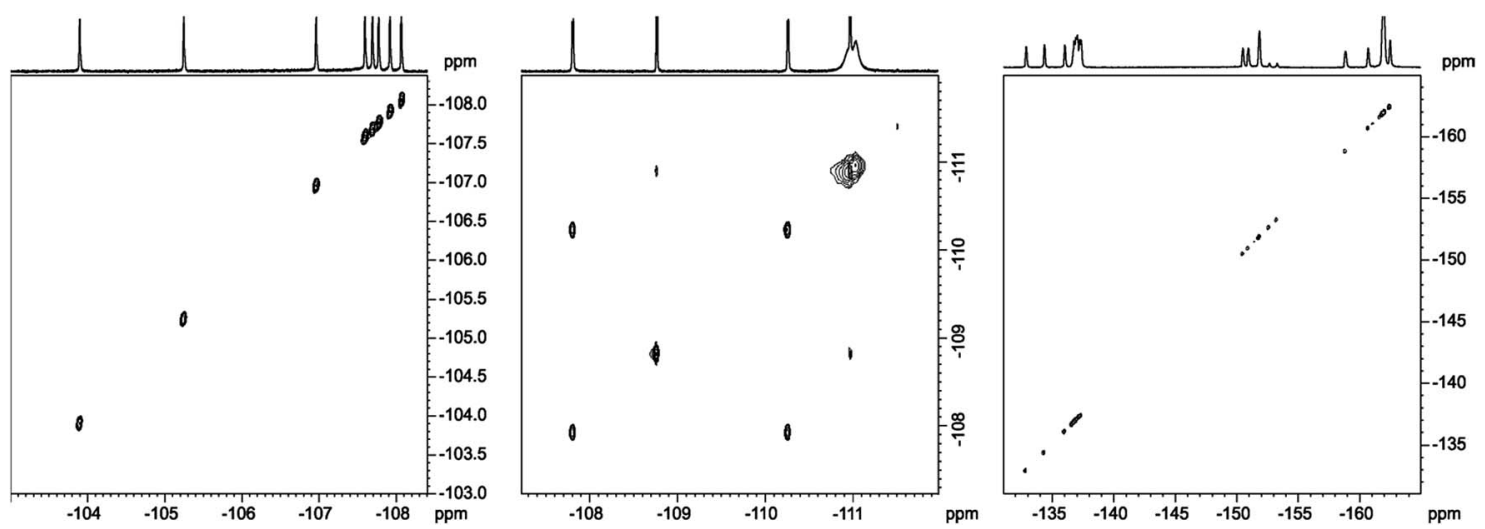

Fig. $12{ }^{19} \mathrm{~F}\left\{{ }^{1} \mathrm{H}\right\}-{ }^{19} \mathrm{~F}\left\{{ }^{1} \mathrm{H}\right\} 2 \mathrm{D}$ EXSY spectra recorded for compound 1 (left), 2 (middle), 3 (right) at temperature $373 \mathrm{~K}, 353 \mathrm{~K}, 373 \mathrm{~K}$, respectively. The spectra obtained in toluene- $\mathrm{d}_{8}$ at $600 \mathrm{MHz}$ spectrometer

possible to observe lineshape effect for protons in ortho position in A ring starting from $333 \mathrm{~K}$, but it was not possible to observe coalescence. It was not possible to observe lineshape effect for $\mathrm{D}$ ring signals. Unfortunately, it was not possible to determine the precise value of rotation barrier due to complex 5 spin system for each ring, additionally complicated by strong overlapping of meta and para signals. In this case we estimated only Gibbs free energy from coalescence temperature. It was $c a .-16 \mathrm{kcal} \mathrm{mol}^{-1}$ for $\mathrm{B}$ and $\mathrm{C}$ rings. In this case we observed similar behaviour of meso-rings like in case 3,5-difluorophenyl analogue - B and C rings have the smallest rotational barrier, A ring has higher rotational barrier and $\mathrm{D}$ ring has the highest rotational barrier. This observation is easy to understand - D ring has higher

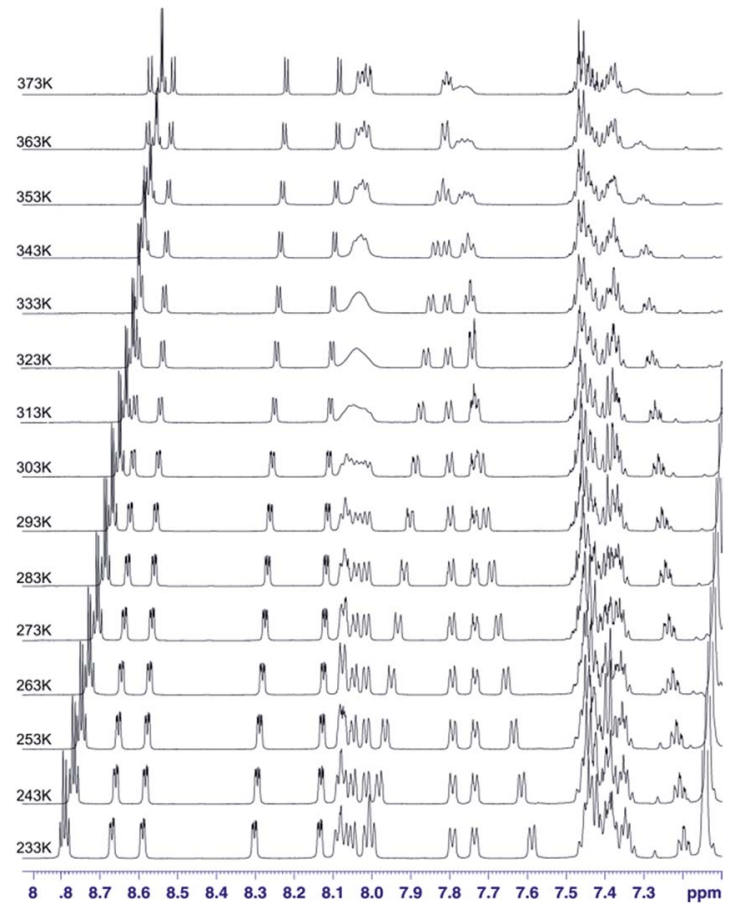

Fig. $13{ }^{1} \mathrm{H}$ VT spectra in the $233-373 \mathrm{~K}$ temperature range recorded in toluene- $d_{8}$ for chlorin 4 . The spectra obtained at $600 \mathrm{MHz}$ spectrometer. activation energy than A ring due to additional hindrance caused by nitro group. Of course both of these rings have larger rotation activation energy then $\mathrm{B}$ and $\mathrm{C}$ ring, caused by strong influence of additional $N$-methylpyrrolidine ring near to A and $\mathrm{D}$ rings. It means that substitution at meta position has no significant steric or electronic effect for rotation barrier.

\section{Conclusions}

The major aim of our investigation is to understand and explain the influence of modifications of the structures of fluorinated pyrrolidine-fused chlorins on the dynamic processes. These compounds were synthesized and characterized in detail. The rotational dynamic of aryl rings in meso-position of chlorins was examined by VT ${ }^{1} \mathrm{H}$ and ${ }^{19} \mathrm{~F}$ 1D NMR spectroscopy and ${ }^{19} \mathrm{~F}$ $\left\{{ }^{1} \mathrm{H}\right\}{ }^{19} \mathrm{~F}\left\{{ }^{1} \mathrm{H}\right\}$ 2D EXSY experiments. The calculated activation energies for aryl substituents in our compounds were very similar to other porphyrinoids. We proved that even small modification in aryl rings may have an effect on rotation of these rings. Our results show that introduction of atoms even as small as fluorine in ortho position in aryl rings causes an inhibitation of rotation. This is due to the increased steric bulk of the hydrogens in $\beta$-pyrrolic positions and fluorine atoms. Natural Bond Orbital (NBO) analysis did not reveal specific interactions between the electron-lone-pairs of fluorine atoms and the $\pi$-cloud of the macroring (see ESI $\dagger$ ) ${ }^{46}$ In nonfluorinated chlorin a rotational dynamic of aryl ring can be controlled by temperature.

\section{Experimental details}

\section{General information}

The chlorins 1-4 were prepared using chemicals which were purchased from Sigma Aldrich, TCI and used without further purification. Reagent grade solvents were purchased from Polish Chemicals Reagents and were distilled prior to use. Silica gel columns for chromatography were prepared with silica (Kieselgel 60, 200-400 mesh). All NMR experiments were run on a $600 \mathrm{MHz}$ Bruker Avance III spectrometer equipped with BBOF probhead operating at $600.13,564.69,150.92 \mathrm{MHz}$ for ${ }^{1} \mathrm{H},{ }^{19} \mathrm{~F}$ 
and ${ }^{13} \mathrm{C}$ nuclei, respectively. 2D ${ }^{1} \mathrm{H}-{ }^{19} \mathrm{~F}$ HOESY, ${ }^{19} \mathrm{~F}-{ }^{19} \mathrm{~F}$ EXSY and $2 \mathrm{D}{ }^{1} \mathrm{H}-{ }^{1} \mathrm{H}$ ROESY experiments were measured with $200 \mathrm{~ms}$ mixing time. ${ }^{1} \mathrm{H}-{ }^{19} \mathrm{~F} 2 \mathrm{D}$ HETCOR correlation was optimized for $10 \mathrm{~Hz}{ }^{1} \mathrm{H}^{1}{ }^{19} \mathrm{~F}$ coupling constants. VT experiment was carried automatic with automatic mode (using modified au zgvt script) with at least $20 \mathrm{~min}$ stabilization of temperature at target temperature with automatic shimming and probhead tuning after temperature equilibration. The following abbreviations were used to describe peak splitting patterns when appropriate: $\mathrm{br}=$ broad singled, $\mathrm{s}=$ singlet, $\mathrm{d}=$ doublet, $\mathrm{t}=$ triplet, $\mathrm{q}=$ quartet, $\mathrm{dd}=$ doublet of doublets, $\mathrm{bm}=$ broad multiplet and $\mathrm{m}$ $=$ multiplet. Coupling constants $J$ are reported in Hz. UV-VIS spectra were obtained on Specord S600 "Analytik jena AG". Mass spectra of obtained compounds were registered by MALDI-TOF Mass Spectrometer - PerSeptive. All calculations were carried out using the Gaussian09 program package. ${ }^{42}$ For geometry optimization of all structures B3LYP and basis set 6$311++\mathrm{g}(\mathrm{d}, \mathrm{p})$ have been used.

Synthesis of porphyrin 5. Porphyrin 5 was prepared in accordance to a previously described method, ${ }^{38}$ with the following procedure. 2,6-Difluorobenzaldehyde (6.96 mL, 0.06 $\mathrm{mol})$ was dissolved in a mixture of nitrobenzene $(105 \mathrm{~mL})$ and acetic acid $(210 \mathrm{~mL})$ and the temperature was raised to $120{ }^{\circ} \mathrm{C}$. Afterwards, pyrrole $(4.2 \mathrm{~mL}, 0.06 \mathrm{~mol})$ was added. The mixture was stirred for $1 \mathrm{~h}$. Then, the mixture was cooled and $30 \mathrm{~mL}$ methanol was added. The crystals were filtered off and washed with water and methanol. A sample was recrystallized from dichloromethane/methanol to afford $0.34 \mathrm{~g}$ (11\%) porphyrin as dark purple crystals. ${ }^{1} \mathrm{H}$ NMR $\left(500 \mathrm{MHz}, \mathrm{CDCl}_{3}\right) \delta-2.77$ (bs, 2H), 7.37-7.40 (m, 8H), 7.77-7.83 (m, 4H), 8.88 (s, 8H). MS (MALDI TOF) $m / z=759.6[\mathrm{M}+\mathrm{H}]^{+}$.

Synthesis of porphyrin 6 . The synthesis of the porphyrin 6 has been adapted from the synthesis reported by Alder et al. ${ }^{39}$ with slight modification. To a refluxing propionic acid $(60 \mathrm{~mL})$ a 3,5-difluorobenzaldehyde $(6.72 \mathrm{~mL}, 0.06 \mathrm{~mol})$ and pyrrole $(4.2$ $\mathrm{mL}, 0.06 \mathrm{~mol}$ ) was added. The reaction mixture was vigorously stirred for $1 \mathrm{~h}$ in reflux. After that, reaction was cooled to room temperature and $30 \mathrm{~mL}$ methanol was added. The purple crystals were filtered off and washed with water and methanol, then dried. Porphyrin was obtained as purple crystals in $0.39 \mathrm{~g} 12 \%$ yields. ${ }^{1} \mathrm{H}$ NMR $\left(500 \mathrm{MHz} \mathrm{CDCl}_{3}\right) \delta-2.96$ (bs, 2H), 7.29-7.34 (m, $4 \mathrm{H}), 7.75-7.79(\mathrm{~m}, 8 \mathrm{H}), 8.91(\mathrm{~s}, 1 \mathrm{H})$. MS (MALDI TOF) $\mathrm{m} / z=$ $759.6[\mathrm{M}+\mathrm{H}]^{+}$.

\section{General procedures for synthesis of copper complexes of porphyrins $^{43}$}

A mixture of porphyrin $(0.45 \mathrm{mmol})$ in chloroform $(34 \mathrm{~mL})$ and $\mathrm{Cu}(\mathrm{OAc})_{2} \cdot \mathrm{H}_{2} \mathrm{O}(2.25 \mathrm{mmol})$ in methanol $(17 \mathrm{~mL})$ was stirred for $2 \mathrm{~h}$ at room temperature. Reaction was monitored by TLC (hexane : chloroform $4: 1$ ) after which the reaction mixture was poured onto water and extracted with chloroform. The organic layer was dried over $\mathrm{Na}_{2} \mathrm{SO}_{4}$. After evaporation of solvent to dryness afforded dark pink solid of: compound 9 (0.34 g, yield: 93\%), MS (MALDI TOF) $m / z=821.5[\mathrm{M}+\mathrm{H}]^{+}$. Compound 10 (0.33 g, yield: 90\%), MS (MALDI TOF) $m / z=821.5[\mathrm{M}+\mathrm{H}]^{+}$. Compound 11 (0.41 g, yield: 89\%), MS (MALDI TOF) $\mathrm{m} / z=$
1037.1 $[\mathrm{M}+\mathrm{H}]^{+}$. Compound $12(0.28 \mathrm{~g}$, yield: 92\%), MS (MALDI TOF) $m / z=677.3[\mathbf{M}+\mathbf{H}]^{+}$.

\section{General procedures for the nitration complexes of porphyrins $^{44}$}

In round bottom flask cooper complex of porphyrin $(0.4 \mathrm{mmol})$ was dissolved in chloroform $(275 \mathrm{~mL})$ and the solution is heated to reflux. Afterwards, $\mathrm{Cu}\left(\mathrm{NO}_{3}\right)_{2} \cdot 2.5 \mathrm{H}_{2} \mathrm{O}(2 \mathrm{mmol})$ in mixture of acetic acid $(5.5 \mathrm{~mL})$ and acetic anhydrate $(27.5 \mathrm{~mL})$ was added. The reaction was stirred for $2 \mathrm{~h}$ in reflux with TLC monitoring after which it was washed with water, saturated solution of sodium biscarbonate and the organic layer was dried with $\mathrm{MgSO}_{4} / \mathrm{Na}_{2} \mathrm{CO}_{3}$. After evaporating the solvent, the products were isolated by column chromatography (using a chloroform/ $n$-hexane as the eluent) to give: compound 13: $0.28 \mathrm{~g}$, yield $80 \%$, MS (MALDI TOF) $m / z=866.2[\mathrm{M}+\mathrm{H}]^{+}$. Compound $140.26 \mathrm{~g}$, yields 78\%, HRMS (ES+/TOF) $m / z:[\mathrm{M}+\mathrm{H}]^{+}$calcd for $\mathrm{C}_{44} \mathrm{H}_{22} \mathrm{~F}_{8^{-}}$ $\mathrm{N}_{5} \mathrm{O}_{2} \mathrm{CuNa}$ 887.0605; found 887.0582, MS (MALDI TOF) $m / z=$ 866.2 [M $+\mathrm{H}]^{+}$. Compound $150.32 \mathrm{~g}$, yield 75\%, MS (MALDI TOF) $m / z=1082.1[\mathrm{M}+\mathrm{H}]^{+}$. Compound 160.23 , yield 80\%, MS (MALDI) $m / z=722.3[\mathrm{M}+\mathrm{H}]^{+}$.

\section{General procedures of demetallation of copper complex ${ }^{45}$}

Procedure A (for compound 17 and 18). To cooper complex of $\beta$-nitro-porphyrin $(0.3 \mathrm{mmol})$ dissolved in chloroform (27 $\mathrm{mL})$, concentrated $\mathrm{H}_{2} \mathrm{SO}_{4}(2 \mathrm{~mL})$ was added. $\mathrm{CF}_{3} \mathrm{COOH}(4 \mathrm{~mL})$ was then added to this stirred mixture. The reaction was continued with stirring at room temperature for $2 \mathrm{~h}$, after which the mixture was poured onto water $(100 \mathrm{~mL})$. The water phase was extracted with chloroform. The combined organic layers were dried with $\mathrm{MgSO}_{4} / \mathrm{Na}_{2} \mathrm{CO}_{3}$. After evaporating the solvent, the residue was chromatographed (eluent: chloroform $/ n$ hexane $1: 3$ ). Compound 17: $0.23 \mathrm{~g}$, yield: 95\%, ${ }^{1} \mathrm{H}$ NMR (600 MHz, DMF-d $\left.{ }_{7}\right) \delta-2.61$ (bs, 2H), 7.73-7.76 (m, 2H), 7.86-7.90 (m, $6 \mathrm{H}), 8.21-8.30(\mathrm{~m}, 8 \mathrm{H}), 9.15$ (q, $J=4.8 \mathrm{~Hz}, 2 \mathrm{H}), 9.42$ (d, $J=$ $4.8 \mathrm{~Hz}, 1 \mathrm{H}) 9.47-9.51(\mathrm{~m}, 3 \mathrm{H}), 9.79(\mathrm{~s}, 1 \mathrm{H}),{ }^{13} \mathrm{C}$ NMR $(151 \mathrm{MHz}$, $\left.\mathrm{DMF}_{-} \mathrm{d}_{7}\right): \delta$ 111.73-112.26, 115.52, 117.03-117.65, 128.40, 129.14, 129.40, 130.56, 130.66, 131.19, 133.00-133.31, 133.87, 135.76, 156.15, 161.53, 163.16, 163.55. HRMS (ES+/TOF) $\mathrm{m} / \mathrm{z}$ : [M $+\mathrm{H}]^{+}$calcd for $\mathrm{C}_{44} \mathrm{H}_{22} \mathrm{~F}_{8} \mathrm{~N}_{5} \mathrm{O}_{2}$ 804.1646; found 804.1639, MS (MALDI TOF) $m / z=804.7[\mathrm{M}+\mathrm{H}]^{+}$. Compound 18: 0.22 g. Yield: $93 \%,{ }^{1} \mathrm{H}$ NMR $\left(600 \mathrm{MHz}, \mathrm{CDCl}_{3}\right) \delta-2.76(\mathrm{bs}, 2 \mathrm{H}), 7.27-7.29(\mathrm{~m}$, $2 \mathrm{H}), 7.32-7.38(\mathrm{bm}, 3 \mathrm{H}), 7.77-7.82(\mathrm{~m}, 8 \mathrm{H}), 8.78(\mathrm{q}, J=4.7 \mathrm{~Hz}$, $2 \mathrm{H}), 9.00(\mathrm{t}, J=5.1 \mathrm{~Hz}, 2 \mathrm{H}), 9.04(\mathrm{~d}, J=4.9 \mathrm{~Hz}, 1 \mathrm{H}), 9.12(\mathrm{~d}, J=$ $5.0 \mathrm{~Hz}, 1 \mathrm{H}), 9.13(\mathrm{~s}, 1 \mathrm{H}) ;{ }^{13} \mathrm{C} \mathrm{NMR}\left(151 \mathrm{MHz}, \mathrm{CDCl}_{3}\right): \delta 104.06$, 104.23, 104.37, 104.39, 104.473, 104.64, 104.70, 104.80, 117.85, $117.97,118.10,118.39-118.41,118.61,118.65-118.69,118.74$, $118.79,120.69,128.39,129.05,129.65,130.09,131.78,135.24$, 142.22 , 142.46, 143.64, 143.86, 144.12, 145.62, 153.20, 160.53160.76, 162.20-162.42. HRMS (ES+/TOF) $m / z:[\mathrm{M}+\mathrm{H}]^{+}$calcd for $\mathrm{C}_{44} \mathrm{H}_{22} \mathrm{~F}_{8} \mathrm{~N}_{5} \mathrm{O}_{2}$ 804.1646; found 804.1632, MS (MALDI TOF) $\mathrm{m} / \mathrm{z}$ $=804.7[\mathrm{M}+\mathrm{H}]^{+}$.

Procedure $B$ (for compound 19 and 20). To cooper complex of $\beta$-nitro-porphyrin $(0.3 \mathrm{mmol})$ concentrated $\mathrm{H}_{2} \mathrm{SO}_{4}(2 \mathrm{~mL})$ was added. $\mathrm{CF}_{3} \mathrm{COOH}(4 \mathrm{~mL})$ was then added to this stirred mixture. The reaction continued with stirring at room temperature for 
$1.5 \mathrm{~h}$, after which the mixture was poured onto water and saturated solution of sodium biscarbonate. The water phase was extracted with chloroform. The combined organic layers were dried with $\mathrm{MgSO}_{4}$ and $\mathrm{Na}_{2} \mathrm{CO}_{3}$. After evaporating the solvent, the residue was chromatographed (eluent : chloroform/ $n$-hexane 1 : 3). Compound 19: yield: $0.28 \mathrm{~g}, 90 \%,{ }^{1} \mathrm{H}$ NMR (600 $\left.\mathrm{MHz} \mathrm{CDCl}_{3}\right) \delta-2.78(\mathrm{~s}, 2 \mathrm{H}), 8.82(\mathrm{q}, J=4.7 \mathrm{~Hz}, 2 \mathrm{H}), 9.03-9.08$ (bm, 4H), $9.18(\mathrm{~s}, 1 \mathrm{H}),{ }^{13} \mathrm{C}$ NMR $\left(151 \mathrm{MHz}, \mathrm{CDCl}_{3}\right): \delta 103.27$, $104.17,104.45$, 106.36, 113.31, 114.40-115.09, 128.42, 128.62, $129.68,131.20,135.36,136.83,138.52,140.51,140.79,141.69$, 141.88, 142.63, 143.38, 143.61, 143.82, 145.67, 145.97, 147.29, 147.64, 153.67, 156.86, 162.57, 169.56, MS (MALDI TOF) $m / z=$ $1020.5[\mathrm{M}+\mathrm{H}]^{+}$. Compound 20: $0.19 \mathrm{~g}$, yield: $95 \%,{ }^{1} \mathrm{H}$ NMR $(600$ $\left.\mathrm{MHz} \mathrm{CDCl}_{3}\right) \delta-2.58$ (bs, 2H), 7.73-7.83 (bm, 12H), 8.21-8.27 $(\mathrm{m}, 6 \mathrm{H}), 8.28(\mathrm{~d}, J=7.2 \mathrm{~Hz}, 2 \mathrm{H}), 8.75(\mathrm{q}, J=4.6 \mathrm{~Hz}, 2 \mathrm{H}), 8.92(\mathrm{t}, J$ $=4.6 \mathrm{~Hz}, 2 \mathrm{H}), 8.97(\mathrm{~d}, J=4.9 \mathrm{~Hz}, 1 \mathrm{H}), 9.04(\mathrm{~d}, J=4.9 \mathrm{~Hz}, 1 \mathrm{H})$, $9.08(\mathrm{~s}, 1 \mathrm{H}),{ }^{13} \mathrm{C} \mathrm{NMR}\left(151 \mathrm{MHz}, \mathrm{CDCl}_{3}\right): \delta 120.10,120.58$, $120.85,123.01,126.88,126.91,126.96,127.07,128.01,128.23$, 128.40, 128.54, 128.92, 129.47, 129.91, 131.86, 134.56, 134.70, 134.71, 135.03, 135.05, 135.42, 137.97, 139.33, 140.20, 140.38, $141.11,141.33,141.57,146.04,153.09,156.37,156.57$, MS (MALDI TOF) $m / z=661.7[\mathrm{M}+\mathrm{H}]^{+}$.

\section{General procedure for the 1,3-dipolar cycloadditions}

The synthetic procedure has been reported by Cavaleiro et al. ${ }^{32}$ with slight modification. In round bottom flask a toluene (20 $\mathrm{mL})$ solution of the $\beta$-nitro-5,10,15,20-tetraarylporphyrin (0.01 $\mathrm{mmol}$ ), sarcosine ( 2 equiv), and paraformaldehyde ( 5 equiv) was heated at reflux for $5 \mathrm{~h}$ under a nitrogen atmosphere. After $2.5 \mathrm{~h}$ the additional portions of sarcosine ( 2 equiv), and paraformaldehyde ( 5 equiv) were added and the reaction mixture was refluxed for another $2.5 \mathrm{~h}$ period. After being cooled to room temperature and evaporated, the reaction mixture was applied on the top of a silica gel column. Compound 1: eluent : chloroform, $0.047 \mathrm{~g}$ yield $43 \%,{ }^{1} \mathrm{H}$ NMR $(600 \mathrm{MHz}$, $\left.\mathrm{CDCl}_{3}\right) \delta-1.97(\mathrm{bs}, 2 \mathrm{H}), 2.32(\mathrm{~s}, 3 \mathrm{H}), 2.41(\mathrm{t}, J=9.2 \mathrm{~Hz}, 1 \mathrm{H}), 3.06$ $(\mathrm{d}, J=11.4 \mathrm{~Hz}, 1 \mathrm{H}), 3.33(\mathrm{t}, J=8.4 \mathrm{~Hz}, 1 \mathrm{H}), 4.37(\mathrm{~d}, J=11.7 \mathrm{~Hz}$, $1 \mathrm{H}), 5.70(\mathrm{t}, J=8.9 \mathrm{~Hz}, 1 \mathrm{H}), 7.26-7.36(\mathrm{bm}, 9 \mathrm{H}), 7.71-7.78(\mathrm{bm}$, $4 \mathrm{H}), 8.32(\mathrm{~d}, J=3.0 \mathrm{~Hz}, 4 \mathrm{H}), 8.51(\mathrm{~s}, 1 \mathrm{H}), 8.59(\mathrm{~d}, J=7.3 \mathrm{~Hz}, 2 \mathrm{H})$, $8.74(\mathrm{~d}, J=3.2 \mathrm{~Hz}, 1 \mathrm{H}), 8.80(\mathrm{~d}, J=3.5 \mathrm{~Hz}, 1 \mathrm{H}) .{ }^{13} \mathrm{C} \mathrm{NMR}(151$ $\left.\mathrm{MHz} \mathrm{CDCl}_{3}\right): \delta 41.06,62.30,64.06,64.63,98.95,105.75,108.93$, 110.18, 110.97, 111.11-111.41, 111.57, 111.59, 111.72, 111.87, $112.31,112.45,116,12,116.26,116.40,118.03,118.17,118.22$, 118.33 , 118.50, 118.58, 124.16, 124.96, 127.64, 128.19, 128.32, 129.00, 131.03, 131.44, 132.31, 132.61, 133.14, 135.44, 136.29, $140.01,153.15,154.11,156.96,160.85,161.23,161.32,161.7$, 161.82 , 162.23, 162.51, 163.00, 163.35, 163.45, 163.90. HRMS (ES+/TOF) $m / z:[\mathrm{M}+\mathrm{H}]^{+}$calcd for $\mathrm{C}_{47} \mathrm{H}_{29} \mathrm{~F}_{8} \mathrm{~N}_{6} \mathrm{O}_{2}$ 861.2224; found 861.2207, MS (MALDI TOF) $m / z=861.8[\mathrm{M}+\mathrm{H}]^{+}$. Compound 2: eluent: $\mathrm{CHCl}_{3}, 0.059 \mathrm{~g}$ yield $55 \%,{ }^{1} \mathrm{H} \mathrm{NMR}\left(600 \mathrm{MHz}, \mathrm{CDCl}_{3}\right.$ ) $\delta-2.23(\mathrm{~s}, 2 \mathrm{H}), 2.02(\mathrm{t}, J=9.0 \mathrm{~Hz}, 1 \mathrm{H}), 2.31(\mathrm{~s}, 3 \mathrm{H}), 2.85(\mathrm{~d}, J=$ $11.4 \mathrm{~Hz}, 1 \mathrm{H}), 3.29$ (t, $J=9 \mathrm{~Hz}, 1 \mathrm{H}), 4.17(\mathrm{~d}, J=11.4 \mathrm{~Hz}, 1 \mathrm{H}), 5.67$ $(\mathrm{t}, J=8.8 \mathrm{~Hz}, 1 \mathrm{H}), 7.21-7.29(\mathrm{~m}, 7 \mathrm{H}), 7.44(\mathrm{~d}, J=8.4 \mathrm{~Hz}, 1 \mathrm{H})$, $7.51(\mathrm{~d}, J=8.4 \mathrm{~Hz}, 1 \mathrm{H}), 7.57(\mathrm{~d}, J=8.4 \mathrm{~Hz}, 1 \mathrm{H}), 7.64(\mathrm{~d}, J=$ $8.4 \mathrm{~Hz}, 2 \mathrm{H}), 7.68(\mathrm{dd}, J=7.8 \mathrm{~Hz}, 17.4 \mathrm{~Hz}, 2 \mathrm{H}), 8.26(\mathrm{dd}, J=$ $1.6 \mathrm{~Hz}, 4.8 \mathrm{~Hz}, 1 \mathrm{H}), 8.45$ (dd, $J=1.6 \mathrm{~Hz}, 4.8 \mathrm{~Hz}, 1 \mathrm{H}), 8.55$ (q, $J=$
$4.5 \mathrm{~Hz}, 2 \mathrm{H}), 8.72(\mathrm{dd}, J=1.3 \mathrm{~Hz}, 4.7 \mathrm{~Hz}, 1 \mathrm{H}), 8.77(\mathrm{dd}, J=1.1 \mathrm{~Hz}$, $4.8 \mathrm{~Hz}, 1 \mathrm{H}) .{ }^{13} \mathrm{C} \mathrm{NMR}\left(151 \mathrm{MHz}, \mathrm{CDCl}_{3}\right): \delta 41.08,63.52,64.29$, $66.58,103.82$, 104.2, 104.90, 105.28, 110.27, 110.70, 115.80, 117.02-117.442, 120.76, 121.67, 125.11, 125.36, 128.09, 128.58, $132.98,133.41,135.13,135.74,140.14,140.35,141.25,144.15-$ $144.34,152.67,153.42$, 156.24, 159.49, 160.56-160.65, 161.30, 161.80, 162.22-162.31, 162.80, 163.00, 163.46. HRMS (ES+/TOF) $m / z:[\mathrm{M}+\mathrm{H}]^{+}$calcd for $\mathrm{C}_{47} \mathrm{H}_{29} \mathrm{~F}_{8} \mathrm{~N}_{6} \mathrm{O}_{2}$ 861.2224; found 861.2216, MS (MALDI TOF) $m / z=861.8[\mathrm{M}+\mathrm{H}]^{+}$. Compound 3: eluent: diethyl ether : chloroform 1 : 5, $0.058 \mathrm{~g}$ yield 55\%, ${ }^{1} \mathrm{H}$ NMR (600 $\left.\mathrm{MHz} \mathrm{CDCl}_{3}\right) \delta-2.14(\mathrm{~d}, J=16.5,2 \mathrm{H}), 2.38-2.41(\mathrm{~m}, 4 \mathrm{H}), 3.00$ (d, $J=11.4 \mathrm{~Hz}, 1 \mathrm{H}), 3.37-3.40(\mathrm{t}, J=8.4 \mathrm{~Hz}, 1 \mathrm{H}), 4.45$ (d, $J=$ $11.5 \mathrm{~Hz}, 1 \mathrm{H}), 5.69(\mathrm{t}, J=9.0 \mathrm{~Hz}, 1 \mathrm{H}), 8.37(\mathrm{dd}, J=4.8 \mathrm{~Hz}, 1.5 \mathrm{~Hz}$, $1 \mathrm{H}), 8.55(\mathrm{~d}, J=4.8 \mathrm{~Hz}, 1 \mathrm{H}), 8.58(\mathrm{q}, J=4.6 \mathrm{~Hz}, 1 \mathrm{H}), 8.78$ (d, $J=$ $4.2 \mathrm{~Hz}, 1 \mathrm{H}), 8.84(\mathrm{~d}, J=4.7 \mathrm{~Hz}, 1 \mathrm{H}) .{ }^{13} \mathrm{C} \mathrm{NMR}\left(151 \mathrm{MHz}, \mathrm{CDCl}_{3}\right)$ : $\delta$ 40.90, 61.94, 63.69, 64.09, 96.50, 96.73, 69.50, 69.73, 105.47, 106.50, 107.63, 112.90, 114.85-115.37, 124.59, 125.30, 128.03, 128.67, 133.03, 133.523, 135.51, 136.37, 136.71, 137.40, 138.42, 139.11, 140.09, 140.28, 141.44, 142.18, 143.14, 143.96, 145.05, 145.50, 145.67, 146.70, 147.11, 147.34, 148.34, 153.25, 154.13, 157.51, 161.77. HRMS (ES+/TOF) $m / z:[\mathrm{M}+\mathrm{H}]^{+}$calcd for $\mathrm{C}_{47} \mathrm{H}_{17} \mathrm{~F}_{20} \mathrm{~N}_{6} \mathrm{O}_{2}$ 1077.1094; found 1077.1082. MS (MALDI TOF) $m / z=1077.7[\mathbf{M}+\mathrm{H}]^{+}$. Compound 4: eluent: diethyl ether: chloroform 1:5, $0.062 \mathrm{~g}$ yield $57 \%,{ }^{1} \mathrm{H}$ NMR $(600 \mathrm{MHz}$, $\left.\mathrm{CDCl}_{3}\right) \delta-1.95(\mathrm{bs}, 2 \mathrm{H}), 2.21(\mathrm{t}, J=6 \mathrm{~Hz}, 1 \mathrm{H}), 2.28(\mathrm{~s}, 3 \mathrm{H}), 2.90$ $(\mathrm{d}, J=12 \mathrm{~Hz}, 1 \mathrm{H}), 3.24(\mathrm{t}, J=9.0 \mathrm{~Hz}, 1 \mathrm{H}), 4.05(\mathrm{~d}, J=11.4 \mathrm{~Hz}$, $1 \mathrm{H}), 5.71(\mathrm{t}, J=9.0 \mathrm{~Hz}), 7.18-7.30(\mathrm{~m}, 3 \mathrm{H}), 7.64-7.78(\mathrm{~m}, 13 \mathrm{H})$, $7.93-7.940(\mathrm{~m}, 1 \mathrm{H}), 8.00(\mathrm{~d}, J=7.2 \mathrm{~Hz}, 1 \mathrm{H}), 8.08-8.25(\mathrm{~m}, 6 \mathrm{H})$, $8.45(\mathrm{~d}, J=4.2 \mathrm{~Hz}, 1 \mathrm{H}), 8.59$ (q, $J=4.2 \mathrm{~Hz}, 2 \mathrm{H}), 8.71$ (d, $J=$ $4.2 \mathrm{~Hz}, 1 \mathrm{H}), 8.77$ (d, $=4.8 \mathrm{~Hz}, 1 \mathrm{H}) .{ }^{13} \mathrm{C} \mathrm{NMR}\left(151 \mathrm{MHz}, \mathrm{CDCl}_{3}\right)$ : $\delta$ 41.14, 63.79, 64.67, 66.99, 105.53, 112.16, 112.54, 122.98, 123.98, 124.85, 125.15, 125.26, 126.64, 126.70, 126.79, 127.43, $127.79,127.80,127.92$, 127.93, 128.10, 128.18, 128.44, 128.46, $128.67,128.99,132.27,132.77,133.15,133.23,133.84,133.91$, 133.98, 134.09, 135.60, 136.19, 137.81, 138.72, 140.60, 140.86, $141.59,141.62,141.75,153.07,153.84,156.37,159.57,717.8, \mathrm{MS}$ (MALDI TOF) $m / z=[\mathrm{M}+\mathrm{H}]^{+}$.

\section{Acknowledgements}

This research has been financially supported by the Polish National Center of Sciences (Grant No. 2013/11/N/ST5/02040). We gratefully thank the Tomasz Pawlak for help with NBO analysis.

\section{References}

1 C. M. Che, V. K. Y. Lo, C. Y. Zhou and J. S. Huang, Chem. Soc. Rev., 2011, 40, 1950.

2 M. I. J. Stich, L. H. Fischer and O. S. Wolfbeis, Chem. Soc. Rev., 2010, 39, 3102.

3 C. M. Drain, K. C. Russell and J. M. Lehn, Chem. Commun., 1996, 337.

4 L. R. Milgrom, The Colours of life, Oxford University, Oxford, U. K., 1997, ch. 7.

5 K. Licha, Top. Curr. Chem., 2002, 222, 1. 
6 T. Gośliński and J. Piskorz, J. Photochem. Photobiol., C, 2011, $12,304$.

7 E. G. Azenha, A. C. Serra, M. Pineiro, M. M. Pereira, J. S. d. Melo, L. G. Arnaut, S. J. Formosinho and A. M. de'A. Rocha Gonsalves, Chem. Phys., 2002, 280, 177.

8 A. Serra, M. Pineiro, C. I. Santos, A. M. d'A. Rocha Gonsalves, M. Abrantes, M. Laranjo and M. F. Botelho, Photochem. Photobiol., 2010, 86, 206.

9 C. J. P. Monteiro, J. Pina, M. M. Pereira and L. G. Arnaut, Photochem. Photobiol. Sci., 2012, 11, 1233.

10 M. M. Pereira, C. J. P. Monteiro, A. V. C. Simões, S. M. A. Pinto, A. R. Abreu, G. F. F. Sá, E. F. F. Silva, L. B. Rocha, J. M. Dąbrowski, S. J. Formosinho, S. Simões and L. G Arnaut, Tetrahedron, 2010, 66, 9545.

11 A. Kimura, K. Funatsu, T. Imamura, H. Kido and Y. Sasaki, Chem. Lett., 1995, 207.

12 N. Kariya, T. Imamura and Y. Sasaki, Inorg. Chem., 1998, 37, 1658.

13 J. Li, A. Ambroise, S. I. Yang, J. R. Diers, J. Seth, C. R. Wack, D. F. Bocian, D. Holten and J. S. Lindsey, J. Am. Chem. Soc., 1999, 121, 8927.

14 B. Boitrel, A. Lecas, Z. Renko and E. Rose, Chem. Commun., 1985, 1820.

15 G. S. Kottas, L. I. Clarke, D. Horinek and J. Michl, Chem. Rev., 2005, 105, 1281.

16 E. R. Kay, D. A. Leigh and F. Zerbetto, Angew. Chem., Int. Ed., 2007, 46, 72 .

17 S. Erbas-Cakmak, D. A. Leigh, C. T. McTernan and A. L. Nussbaumer, Chem. Rev., 2015, 115(18), 10081.

18 K. Tashiro, Y. Hirabayashi, T. Aida, K. Saigo, K. Fujiwara, K. Komatsu, S. Sakamoto and K. Yamaguchi, J. Am. Chem. Soc., 2002, 124, 12086.

19 M. Nakamura, K. Kishimoto, Y. Kobori, T. Abe, K. Yoza and K. Kobayashi, J. Am. Chem. Soc., 2016, 138, 12564.

20 T. Lang, A. Guenet, E. Graf, N. Kyritsakas and M. W. Hosseini, Chem. Commun., 2010, 46, 3508.

21 T. Lang, E. Graf, N. Kyritsakas and M. W. Hosseini, New J. Chem., 2013, 37, 112.

22 A. B. C. Deutman, T. Woltinge, J. M. M. Smits, R. de Gelder, J. A. A. W. Elemans, R. J. M. Nolte and A. E. Rowan, Molecules, 2014, 19, 5278.

23 S. Ishihara, J. Labuta, W. van Rossom, D. Ishikawa, K. Minami, J. P. Hill and K. J. Ariga, Phys. Chem. Chem. Phys., 2014, 16, 9713.

24 P. Mondal and S. P. Rath, Chem.-Eur. J., 2016, 22, 5607.

25 P. A. Liddell, G. Kodis, A. L. Moore, T. A. Moore and D. Gust, J. Am. Chem. Soc., 2002, 124, 7668.

26 L. K. Gottwald and E. F. Ullman, Tetrahedron Lett., 1969, 36, 3071.

27 C. J. Medforth, in The Porphyrin Handbook, ed. K. M. Kadish, K. M. Smith and E. Guilard, Academic Press, New York, 2000, vol. 5, pp. 3-74.

28 H. Scheer and J. J. Katz, in Porphyrins and Metalloporphyrins, ed. K. M. Smith, Elsevier, Amsterdam, 1975, p. 399.
29 T. Janson and J. J. Katz, in The Porphyrins, ed. D. Dolphin, Academic Press, New York, 1979, IV, ch. 1.

30 L. Noss, P. A. Liddell, A. L. Moore, T. A. Moore and D. Gust, J. Phys. Chem. B, 1997, 101, 458.

31 A. M. Stolzenberg and G. S. Haymond, Inorg. Chem., 2002, 41, 300.

32 A. M. G. Silva, A. C. Tome, M. G. P. M. S. Neves, A. M. S. Silva and J. A. S. Cavaleiro, J. Org. Chem., 2005, 70, 2306.

33 J. Flemming and D. Dolphin, Tetrahedron Lett., 2002, 43, 7281.

34 M. Gałęzowski and D. T. Gryko, J. Org. Chem., 2006, 71, 5942. 35 X. F. Li, J. P. Zhuang, Y. L. Li, H. B. Liu, S. Wang and D. B. Zhu, Tetrahedron Lett., 2005, 46, 1555.

36 X. G. Liu, Y. Q. Feng, X. F. Hu and X. G. Li, Synthesis, 2005, 20, 3632.

37 A. M. G. Silva, A. C. Tome, M. G. P. M. S. Neves, A. M. S. Silva and J. A. S. Cavaleiro, Chem. Commun., 1999, 1767.

38 A. M. d'A. Rocha Gonçalves, J. M. T. B. Varejão and M. M. Pereira, J. Heterocycl. Chem., 1991, 28, 635.

39 A. D. Adler, F. R. Longo, J. D. Finarelli, J. Goldmacher, J. Assour and L. Korsakoff, J. Org. Chem., 1967, 32, 476.

40 J. C. Hierso, Chem. Rev., 2014, 114, 4838.

41 K. Yoshida, G. Copley, M. Mori and A. Osuka, Chem.-Eur. J., 2014, 20, 10065.

42 M. J. Frisch, G. W. Trucks, H. B. Schlegel, G. E. Scuseria, M. A. Robb, J. R. Cheeseman, G. Scalmani, V. Barone, B. Mennucci, G. A. Petersson, H. Nakatsuji, M. Caricato, X. Li, H. P. Hratchian, A. F. Izmaylov, J. Bloino, G. Zheng, J. L. Sonnenberg, M. Hada, M. Ehara, K. Toyota, R. Fukuda, J. Hasegawa, M. Ishida, T. Nakajima, Y. Honda, O. Kitao, H. Nakai, T. Vreven, J. A. Montgomery Jr, J. E. Peralta, F. Ogliaro, M. Bearpark, J. J. Heyd, E. Brothers, K. N. Kudin, V. N. Staroverov, T. Keith, R. Kobayashi, J. Normand, K. Raghavachari, A. Rendell, J. C. Burant, S. S. Iyengar, J. Tomasi, M. Cossi, N. Rega, J. M. Millam, M. Klene, J. E. Knox, J. B. Cross, V. Bakken, C. Adamo, J. Jaramillo, R. Gomperts, R. E. Stratmann, O. Yazyev, A. J. Austin, R. Cammi, C. Pomelli, J. W. Ochterski, R. L. Martin, K. Morokuma, V. G. Zakrzewski, G. A. Voth, P. Salvador, J. J. Dannenberg, S. Dapprich, A. D. Daniels, O. Farkas, J. B. Foresman, J. V. Ortiz, J. Cioslowski and D. J. Fox, Gaussian 09, Revision B. 01, Gaussian, Inc., Wallingford, CT, 2010.

43 B. P. Bandgar and P. Gujarathi, J. Chem. Sci., 2008, 120, 259. 44 R. Prasath, R. Butcher and P. Bhavana, Spectrochim. Acta, Part A, 2012, 87, 258.

45 P. Wyrębek and S. Ostrowski, J. Porphyrins Phthalocyanines, 2007, 11, 822.

46 E. D. Glendening, J. K. Badenhoop, A. E. Reed, J. E. Carpenter, J. A. Bohmann, C. M. Morales, and F. Weinhold, NBO 50. Theoretical Chemistry Institute, University of Wisconsin, Madison, WI, 2001. 